\title{
原発性肺癌を疑い胸腔鏡下肺部分切除術を 施行した症例の検討
}

\author{
Analysis of Small Peripheral Pulmonary Tumors Treated by \\ Thoracoscopic Excisional Biopsy (Wedge Resection) \\ on a Suspicion of Primary Lung Cancer
}

矢満田 健 $^{1} \cdot$ 宮澤正久 $^{1} \cdot$ 近藤竜一 $^{1} \cdot$ 町田恵美 $^{1} \cdot$ 吉田和夫 $^{1}$

羽生田正行 ${ }^{1} \cdot$ 天野 $^{\text {純 }^{1} \cdot \text { 本田孝行 }^{2} \cdot \text { 久保恵嗣 }}{ }^{3} \cdot$ 曽根脩輔 ${ }^{4}$

要旨：胸腔鏡下肺部分切除を施行した原発性肺癌疑い未梢性肺腫瘤40例について検討した。術 前CT画像上の腫瘤径は $5 \sim 30 \mathrm{~mm}$, 平均 $11.9 \mathrm{~mm}$ であった. 術中小開胸が 4 例で必要と なったが, 胸膜面から $2 \mathrm{~cm}$ 距離にある腫瘤に対しては, 十分な切除マージンをとるた め開胸が必要と思われた。確定診断は原発性肺癌27例, 異型腺腫様過形成 3 例, 過誤腫 2 例, 炎症性腫瘤 6 例, 肺内リンパ節 2 例であった。原発性肺癌27例の組織学的腫瘍径 は 3 〜 $22 \mathrm{~mm}$, 平均 $10.9 \mathrm{~mm}$ で18例が10 $\mathrm{mm}$ 以下であった. 18例に対して葉切除, 郭清を 施行した. 他は, 1 例に区域切除を, 8例については部分切除のみとした. 術後 4 -54力 月の経過で全例無再発生存中である.肺癌治療成績の向上のため, CT検診による微小肺 癌の発見, 早期外科治療は重要であると思われる。従来の方法では確定診断困難な末梢 性肺腫瘤性病変で, 原発性肺癌を強く疑う病変に対しては, 積極的に胸腔鏡手術を施行 すべきと思われた。

〔肺癌 39(2)：137〜143，1999〕

Key words: Small peripheral lung tumor, Small peripheral lung cancer,

Thoracoscopic lung resection, Thoracoscopic lung biopsy,

Limited operation

\section{はじめに}

最近, 肺癌一次検診へのCT検查の導入により, 非常に小型の原発性肺癌が発見されるようにな ク，気管支鏡検査をはじめとする術前検查で確 定診断困難な症例が増加している。そのため, 画像上悪性腫瘍が疑われる末梢性肺小腫瘤性病

1. 信州大学第 2 外科

2. 同臨床検査医学

3. 同第 1 内科

4. 同放射線科
変に対する診断および治療を目的とした胸腔鏡 手術が今後増加することが予想される，教室に おいても，1996年より当地方で始まった胸部一 次検診へのラセンCT検診車の導入により, 術前 確定診断困難(胸部単純X線写真では同定困難)な 最大腫瘍径 $10 \mathrm{~mm}$ 前後の微小肺癌症例が急増して いる. 今回，術前確定診断は得られなかったも のの, 画像あるいは経過から原発性肺癌を疑い, 診断および治療目的に胸腔鏡手術を施行した症 例を対象とし, 腫瘤確認 - 切除の問題点, 組織 
Table 1. Cases of thoracoscopic partial resection for the diagnosis of lung tumor.

\begin{tabular}{lll}
\hline Number & \multicolumn{2}{c}{40} \\
Sex & male : 18 & Female $: 22$ \\
Age & $63.0 \pm 8.9$ years $(34 \sim 79$ years $)$ \\
Location of the tumor & RUL : 18 & LUL : 7 \\
& RML : 1 & LLL : 7 \\
& RLL : 7 & \\
\hline
\end{tabular}

RUL : right upper lobe RML : right middle lobe RLL : right lower lobe LUL : left upper lobe LLL : left lower lobe

学的診断結果および現時点での術後成績を検討 した。

\section{対象および方法}

1994年 1 月から 1998年 6 月までに信州大学第 2 外科にて画像所見 $(\mathrm{CT}, \mathrm{MRI})$ あるいは経過か ら，原発性肺癌を疑い確定診断のために胸腔鏡 下肺部分切除術を施行した40例を対象とした。 40例のうち1996年に始まった胸部CT検診で発見 された症例は18例であった。年齢は34歳から 79 歳, 平均63歳で, 性別は男性 18例, 女性 22例で あった。腫瘤の局在は右上葉 18 例, 中葉 1 例, 下葉 7 例および左上葉 7 例，下葉 7 例であった (Table 1). 術前確定診断のための気管支鏡検査 施行回数は 1 回 16例, 2 回 4 例, 3 回 1 例であ つたが，いずれも確定診断は得られなかった。 他の19例については単純胸部X線写真で同定困難 であったため気管支鏡検查は施行されなかった。 また, CTがイド下経皮的針生検を 2 例に施行し たが，2例とも確定診断は得られなかった。全 例, 胸腔鏡を使用し, 腫瘤を含む肺部分切除を 施行後, 切除組織を術中迅速病理診断に提出し た.なお, 部分切除は腫瘍辺縁から $20 \mathrm{~mm}$ 以上離 した切離線で行うことを原則とした。迅速病理 診断で肺癌の確定診断が得られた場合, その病 理所見より部分切除のみか(術前画像上腫瘍最大 径が10 mm以下で, 扁平上皮癌あるいは線維化に 乏しい高分化型腺癌), それ以外は開胸へ移行し て葉切除および縦隔郭清を施行する方針とした。
Table 2. Confirmation of the tumors.

\begin{tabular}{lrr}
\hline Tumor size & $\sim 10 \mathrm{~mm}$ & 23 cases \\
& $11-20 \mathrm{~mm}$ & 16 cases \\
$21 \sim \mathrm{mm}$ & 1 cases \\
& adjacent & 7 cases \\
$\begin{array}{l}\text { Distance from } \\
\text { the pleural surface }\end{array}$ & $\sim 5 \mathrm{~mm}$ & 22 cases \\
& $6-10 \mathrm{~mm}$ & 6 cases \\
& $11-15 \mathrm{~mm}$ & 3 cases \\
& $15 \sim$ & 2 cases \\
Preoperative needle & 10 cases $(25.0 \%)$ \\
localization & \\
Conversion to thoracotomy & 4 cases $(10.0 \%)$ \\
to detect the nodules & \\
\hline
\end{tabular}

なお,腫瘍辺縁からのマージンを $20 \mathrm{~mm}$ 以上とっ た区域切除が可能な症例に対しては，区域切除 の適応とした。

\section{結 果}

1. 腫瘤の確認および切除

40症例の術前CT画像上での腫瘤最大径は 5 か ら $30 \mathrm{~mm}$, 平均 $11.9 \mathrm{~mm}$ であり, 腫瘤径 $10 \mathrm{~mm}$ 以 下が23例, $11 \mathrm{~mm}$ 以上 $20 \mathrm{~mm}$ 以下が16例, $21 \mathrm{~mm}$ 以上が 1 例であった.またCT画像上での肺胸膜 表面から腫瘤縁までの最短距離は，接するもの が 7 例, $5 \mathrm{~mm}$ 以下が 22 例, 6 - 10mmが 6 例, 11 -15mmが 3 例， $16 \mathrm{~mm}$ 以上が 2 例であった。 術前(術当日朝)CTガイド下にフックワイヤーに よるマーキングを10例(25\%)に施行した。40例 中36例については, 腫瘤確認および切除は胸腔 鏡下に可能であったが，4症例(10\%)に小開胸 が必要となった(Table 2).小開胸が必要であっ た 4 症例について，その原因を検討すると高度 な㾍着(ほぼ全面痛着)が原因であった症例が 2 例, 残りの 2 例は胸膜表面からの距離が $20 \mathrm{~mm}$ と いずれも腫瘤が比較的剁部に存在し，腫瘤の確 認掞よび腫瘍辺縁から十分なマージンをとった 切除のために小開胸が必要となった (Table 3$)$. 術前フックワイヤーによるマーキングを施行し た10症例は全例容易に腫瘤を含む肺部分切除が 施行できた。

\section{2. 組織学的診断}

術中迅速組織診断の結果は, 原発性肺癌 27 例 
Table 3. Cases requiring conversion to thoracotomy for partial resection.

\begin{tabular}{ccclc}
\hline Case & $\begin{array}{c}\text { Tumor } \\
\text { size }\end{array}$ & $\begin{array}{c}\text { Distance from } \\
\text { the pleural surface }\end{array}$ & Diagnosis & $\begin{array}{c}\text { Cause for the } \\
\text { conversion }\end{array}$ \\
\hline 1 & $20 \mathrm{~mm}$ & $5 \mathrm{~mm}$ & granuloma & adhesion \\
2 & $7 \mathrm{~mm}$ & $20 \mathrm{~mm}$ & granuloma & difficulty in resection \\
3 & $10 \mathrm{~mm}$ & $5 \mathrm{~mm}$ & lung cancer & adhesion \\
4 & $3 \mathrm{~mm}$ & $20 \mathrm{~mm}$ & lung cancer & difficulty in resection \\
\hline
\end{tabular}

(67.5\%), 異型腺腫様過形成 3 例, 過誤腫 2 例, 炎症性腫瘤 6 例, 肺内リンパ節 2 例であった。 なお，CT検診発見症例に限定すると全18例中， 原発性肺癌 11例, 異型腺腫様過形成 2 例, 肺過 誤腫 2 例，クリプトコッカス 1 例，非特異的炎 症 1 例，肺内リンパ節 1 例であった。原発性肺 癌27例の組織型は腺癌が25例, 扁平上皮癌と小 細胞癌がそれぞれ 1 例であった (Table 4).

\section{3。良性病变症例}

組織学的に良性病変と診断された13例のうち， 異型腺腫様過形成 3 例と過誤腫 2 例を除く 8 症 例について術前画像所見を検討した (Table 5). 8 症例の術前CT画像上の腫瘤径は 8〜20 $\mathrm{mm}$, 平均 $10.7 \mathrm{~mm}$, 一方組織学的腫瘤径は $3 \sim 20 \mathrm{~mm}$, 平均 $9.0 \mathrm{~mm}$ であった. 術前高分解能CT検查では 8 例中 7 例については悪性を強く疑う所見を呈 した. 胸部MRIを施行した 6 例中 5 例について は造影パターンが悪性病変を疑う所見であった。 症例 4 は術前の経過で腫瘤の明らかな増大傾向 があり，画像的には悪性所見に乏しかったもの の，外科的切除を施行した。良性疾患であった 8 症例中 2 例に, 小開胸が必要となったが, 全
Table 4. Pathologic diagnosis of 40 cases.

\begin{tabular}{lc}
\hline Disease & No. of cases \\
\hline Primary lung cancer & 27 \\
$\quad$ adenocarcinoma & 25 \\
squamous cell carcinoma & 1 \\
small cell carcinoma & 1 \\
Atypical adenomatous hyperplasia & 3 \\
Hamartoma & 2 \\
Inflammatory lesion & 6 \\
Intrapulmonary lymphnode & 2 \\
\hline
\end{tabular}

例合併症もなく術後の経過は良好であった。

\section{4. 原発性肺癌症例}

迅速病理診断で原発性肺癌と診断された27例 (腺癌 25 例, 扁平上皮癌 1 例, 小細胞癌 1 例) の 術前CT画像上の腫瘤径は $6 \sim 30 \mathrm{~mm}$, 平均 12.3 $\mathrm{mm}$ であった。一方, 組織学的腫瘍最大径は最小 $3 \mathrm{~mm}$ から最大 $22 \mathrm{~mm}$, 平均 $10.9 \mathrm{~mm}$ で, $10 \mathrm{~mm}$ 以下が18例, 11 から $20 \mathrm{~mm}$ が 8 例, $21 \mathrm{~mm}$ 以上が 1 例であった。これら 27 例に対して診断確定後, 選択施行した手術術式は一期的に葉切除, 縦隔 郭清を施行した症例が14例，二期的に同様の標 準術式を施行した症例が 4 例であった。なお,

Table 5. Cases diagnosed a benign by intraoperative pathologic findings.

\begin{tabular}{ccclll}
\hline Case & $\begin{array}{c}\text { Age } \\
\text { Sex }\end{array}$ & $\begin{array}{c}\text { Tumor } \\
\text { size }(\mathrm{mm})\end{array}$ & \multicolumn{1}{c}{ Diagnosis } & CT findings & MRI findings \\
\hline 1 & $59 \mathrm{~F}$ & 9 & granuloma & malignancy & malignancy \\
2 & $72 \mathrm{~F}$ & 20 & granuloma & malignancy & NE \\
3 & $71 \mathrm{~F}$ & 7 & granuloma & malignancy & malignancy \\
4 & $67 \mathrm{M}$ & 7 & old inflammation & benign & NE \\
5 & $55 \mathrm{~F}$ & 6 & intrapulmonary LN & malignancy & malignancy \\
6 & $67 \mathrm{M}$ & 3 & intrapulmonary LN & malignancy & benign \\
7 & $49 \mathrm{M}$ & 15 & old inflammation & malignancy & malignancy \\
8 & $71 \mathrm{~F}$ & 5 & criptococcosis & malignancy & malignancy \\
\hline
\end{tabular}

LN : lymphnode PI : pleural indentation NE : not-examined 
4 例に対して二期的となった理由は迅速診断の 結果等が原因ではなく，4例ともに初期の症例 で，医療側の理由によるものであった。一方， 縮小手術を選択した症例は 9 例で, 区域切除お よび縦隔郭清を 1 例に, 他の 8 例については, 術前患者自身および家族との間でインフォーム ドコンセントを十分行った上で, 迅速組織診断 結果を参考として(線維化に乏しい高分化型腺癌 で切除マージンが $20 \mathrm{~mm}$ 以上ある), 胸腔鏡下肺 部分切除のみとした (Table 6).葉切除あるいは 区域切除, および縦隔郭清を施行した原発性肺 癌19症例の組織学的診断は全例リンパ節転移は 認められず, stage I Aであった. 原発性肺癌で あった 27 症例全例, 術後 $4 \sim 54$ 力月 (平均 18 力) 経過した現在，無再発生存中である。

\section{考 察}

近年, 肺癌一次検診へのCT検査の導入をはじ めとする診断技術の進歩により，より小型の肺 癌症例が発見されるようになり, 術前気管支鏡 では確定診断困難な微小肺癌症例が増加してい る。これら微小肺癌の発見, 診断および早期外 科治療は, 肺癌治療戦略上, 今後重要であると 思われる。当施設でも1996年より胸部一次検診 にラセンCT検診車が導入され ${ }^{1)}$, 以後術前気管 支鏡による確定診断困難な腫瘍最大径が $10 \mathrm{~mm}$ 前 後の末梢性微小肺癌症例が年々増加しており, 今後さらなる増加が予想される。 今回これら最 近のCT検診発見例も含め, 現在までに教室で診 断のために，まず，肺腫瘤に対して胸腔鏡下肺 部分切除術を施行した原発性肺癌疑い症例の検 討を行い, 診断目的の胸腔鏡下肺部分切除術の 有用性および問題点について評価した。

肺腫瘤性病変に対する胸腔鏡下肺部分切除手 術では腫瘤の確認が術中可能かどうかが重要な 問題である.Demmyら ${ }^{2)}$ は, 術前CT画像上での 腫瘤径と腫瘤存在部位(胸膜面からの最短距離) の 2 因子より腫瘤確認の困難度を術前に予測す る方程式を作成しその有用性について報告して いる。腫瘤径および腫瘤の性状に関しては, 確 かに小型で淡い陰影の場合触知不能な症例も多 く存在するが, 局在診断補助を目的とした, CT
Table 6. Operative procedures for lung cancer.

\begin{tabular}{|c|c|}
\hline Operation & No. of cases \\
\hline Lobectomy & 18 \\
\hline \multicolumn{2}{|l|}{+ mediastinal dissection } \\
\hline Single operation & 14 \\
\hline Staged operation & 4 \\
\hline $\begin{array}{l}\text { Segmentectomy } \\
+ \text { mediastinal dissection } \\
\quad \text { (Single operation })\end{array}$ & 1 \\
\hline Wedge resection only & 8 \\
\hline
\end{tabular}

ガイド下術前マーキング3) 6), 色素の術前注入7), あるいは術中超音波の使用 ${ }^{6)}$, その他の工夫 ${ }^{8), 91}$ 等多くの手法が報告されるに至り，現在では大 きな問題ではなくなったと思われる。われわれ の施設でも1997年より術中確認が難しいと考え られる微小腫瘤に対しては積極的に術前CTがイ ド下マーキングを施行する方針とし, 現在腫瘤 径による適応外はないと考えている. 我々の施 設ではCTがイド下マーキングは術当日朝施行し ているが, 比較的短時間で患者の負担も軽く施 行できることより, あまり厳密な適応を決めず に積極的に施行してよいと考える. 一方, 肺胸 膜から腫瘤までの距離(腫瘤の深さ)に関する今 回の検討では, 最短距離が $15 \mathrm{~mm}$ を超之る症例 2 例(約 $20 \mathrm{~mm} の 2$ 症例)で腫瘤辺縁から $20 \mathrm{~mm}$ 以 上の十分な距離を置いた部分切除が困難であっ たために結果的に小開胸が必要となった. 胸膜 からの距離からみた胸腔鏡下肺部分切除術の限 界については, $10 \mathrm{~mm}$ 程度が限界とする報告 ${ }^{6)}$, あるいは20mm以上でも可能とする報告年等さま ざまであるが, Downeyら ${ }^{10)}$ も報告している如く, 腫瘍マージンを十分とらなかったことによる胸 腔内播種再発あるいは切除端再発の可能性を考 えると, 原発性肺癌疑い腫瘤性病変については, 胸膜面からの距離が $15 \mathrm{~mm}$ 以内の腫瘤を胸腔鏡下 肺部分切除術の適応と考えるのが妥当ではない かと思われた。胸膜面からの距離が $15 \mathrm{~mm}$ を超之 るような症例に対しては, 開胸による部分切除 を選択すべきと思われた。

今回, 40例の胸腔鏡下肺部分切除術施行症例 のうち原発性肺癌と診断された症例は 27 例( $67.5 \%)$ 
であった.40例の腫瘍径の平均が $11.9 \mathrm{~mm}$ で，う ち23例は $10 \mathrm{~mm}$ 以下であったということから考之 ると, 許容されうる範囲内の結果ではないかと 思われる。しかし一方で, 低侵襲で今回対象症 例の術後に問題となる合併症がなかったとはい え，できる限り，良性疾患に対する不要な手術 を減らす努力は必須である，ただし，今回組織 診断結果で良性疾患であった 8 症例について画 像所見の再検討を行ったが, CT所見上の辺縁の 性状, 内部構造, 胸膜陥入像あるいは周囲血管 の集束像等，あるいはMRIの造影パターン等の 画像診断で, 術前良性病変と診断して経過観察 とするのは危険と思われ, 肺小腫瘤性病変に対 する現在の術前画像診断の限界が明らかとなっ た. 最近の微小肺癌の出現により, 結核性肉芽 腫と肺癌の鑑別に加之, 微小肺癌と器質化肺炎 あるいは肺内リンパ節の鑑別, さらには微小肺 癌と異型腺腫様過形成の鑑別のための術前診断 技術の開発が今後の課題ではないかと考えられ た。

今回原発性肺癌と診断された 27 症例の組織学 的検索による最大腫瘍径は 27 例中 18 例が $10 \mathrm{~mm}$ 以 下の微小肺癌症例であった。われわれは, 以前, 最大腫瘍径 $20 \mathrm{~mm}$ 以下の肺葉切除 (あるいは肺摘 除)および縦隔郭清を施行した非小細胞肺癌 114 例を対象とし, 腫瘍径とN因子との関連を検討し た結果, 最大腫崵径 $12 \mathrm{~mm}$ 以下の 33 例については 全例N0で，かつ脈管およびリンパ管侵襲を認め なかったことから,腫瘍径 $10 \mathrm{~mm}$ 以下の非小細胞
肺癌症例に対する積極的縮小手術(肺葉切除未満 の肺切除あるいはリンパ節郭清の省略等)施行の 妥当性について報告した ${ }^{11)}$. 肺癌に対する縮小 手術に関しては，現在のところ結論はでておら ず，一方で腫瘍径が小さくても葉切除，郭清を 行うべきという意見もあるが12),13), 小型肺癌(微 小肺癌)に対する縮小手術には, 現在多くの呼吸 器外科医が, 注目しているのも事実であろう ${ }^{14), 15)}$. 特に, Noguchiら ${ }^{16)}$ が報告した小型肺腺癌の組 織学的覀型によっては, 区域切除さらには部分 切除で，あるいはリンパ節郭清を省略しても治 瘾可能な症例があると考之られる ${ }^{17)}$ 。われわれ は, 末梢型肺癌で, 腫瘍径が $10 \mathrm{~mm}$ 以下の症例に 対して, 術中迅速診断で扁平上皮癌あるいは線 維化に乏しい高分化型腺癌であった場合, 胸腔 鏡下肺部分切除のみの方針をとりはじめたが, その術後成績に期待している。

今後の肺癌治療成績の向上のためにCT検診に よる微小肺癌の発見, 早期の外科治療は非常に 重要であると思われる。気管支鏡検査ではアプ ロー千不可能で単純胸部X線写真で同定困難な病 変, あるいは今回対象症例では 2 例に施行した のみであるが, 経皮針生検で診断困難な症例に 対しても，胸腔鏡下肺部分切除は安全に施行で き，診断確定に有用であった。十分な専門医に よる画像診断の上で, 悪性を疑う胸膜からの距 離が $15 \mathrm{~mm}$ 以内の末梢性肺腫瘤性病変に対しては 胸腔鏡下肺部分切除を積極的に施行すべきと思 われる。

\section{文 献}

1) Sone S, Takashima S, Li F, et al : Mass screening for lung cancer with mobile spiral computed tomography scanner. Lancet 351 : 1242-1245, 1998.

2) Demmy LD, Wagner-Mann CC, James MA, et al : Feasibility of mathematical models to predict success in video-assisted thoracic surgery lung nodule excision. Am J Surg 174 : 20-23, 1997

3) Sartoris F, Cittadini G, Saitta S, et al : CTguided needle localization of lung nodules for thoracoscopic resection. Eur Radiol 6 : 420-
424, 1996.

4) Kakuda J, Omari B, Renslo R, et al : CT guided needle localization for videothoracoscopic resection of pulmonary nodules. Eur J Med Res 2: 340-342, 1997.

5) 田尻通彦, 石井治彦, 山形達史, 他: CTガイド マーキング法を併用した胸腔鏡下肺部分切除術 の検討. 胸部外科 $50: 55-58,1997$.

6) Mack MJ, Shennib H, Landreneau RJ, et al : Techniques for localization of pulmonary nodules for thoracoscopic resection. J Thorac Cardiovasc Surg 106 : 550-553, 1993. 
7) Nomori H, Horie $\mathrm{H}$ : Colored collagen is a long-kasting point marker for small pulmonary nodules in thoracoscopic operations. Ann Thorac Surg 61 : 1070-1073, 1996.

8) Ohtsuka T, Furuse A, Kohno T, et al : New tactile sensor techniques for pulmonary nodules. Int Surg 82 : 12-14, 1997.

9) Nomori $\mathrm{H}$, Horio $\mathrm{H}$ : Endofinger for tactile localization of pulmonary nodules during thoracoscopic resection. Thorac Cardiovasc Surgeon $44:$ 50-53, 1996.

10) Downey RJ, McCormack P, LoCicero J, et al : Dissemination of malignant tumors after video-assisted thoracic surgery : A report of twenty-one cases. J Thorac Cardiovasc Surg $111: 954-960,1996$.

11）矢満田健, 花岡孝臣, 町田恵美, 他: 末梢型小 型肺癌の手術成績からみた肺癌縮小手術の可能 性. 胸部外科 $51: 17-21,1998$.

12) Ginsberg RJ, Rubinstein L, and the Lung cancer study group : Randomized trial of lobectomy versus limited resection for T1N0 non-small cell lung cancer. Ann Thorac Surg $60: 615-623,1995$.

13）野守裕明，堀尾裕俊：開胸あるいは胸腔鏡下生 検で診断し得た末梢小型肺癌の検討. 日胸外会 誌 $28: 146-148,1997$.

14) Warren WH, Faber LP : Segmentectomy versus lobectomy in patients with stage I pulmonary carcinoma. J Thorac Cardiovasc Surg 107 : 1087-1094, 1994.

15）坪田紀明：肺癌に対する縮小手術. 日外会誌 98: 31-35, 1997.

16) Noguchi M, Morikawa A, Kawasaki M, et al: Small adenocarcinoma of the lung. Cancer $75:$ 2844-2852, 1995.

17）大和 靖, 相馬孝博, 吉谷克雄, 他: 線維化巣 のほとんどない肺野末梢型細気管支肺胞型腺癌 切除例の検討一積極的縮小手術の可能性につい て一. 肺癌 $38: 109-115,1998$. 


\title{
Analysis of Small Peripheral Pulmonary Tumors Treated by Thoracoscopic Excisional Biopsy (Wedge Resection) on a Suspicion of Primary Lung Cancer
}

\author{
Takeshi Yamanda ${ }^{1}$, Masahisa Miyazawa ${ }^{1}$, Ryoichi Kondo ${ }^{1}$ \\ Emi Machida ${ }^{1}$, Kazuo Yoshida ${ }^{1}$, Masayuki Haniuda ${ }^{1}$ \\ Jun Amano ${ }^{1}$, Takayuki Honda ${ }^{2}$,Keishi Kubo ${ }^{3}$ \\ and Shusuke Sone
}

Second Department of Surgery ${ }^{1}$

Department of Laboratory Medicine ${ }^{2}$

First Department of Internal Medicine ${ }^{3}$

Department of Radiology ${ }^{4}$

Shinshu University School of Medicine

\begin{abstract}
We examined the clinicopathological findings of 40 cases of small peripheral lung tumors in which primary lung cancer were suspected and in which thoracoscopic excisional biopsy (wedge resection) was performed. The mean tumor diameter was 11.9 $\mathrm{mm}(5-30 \mathrm{~mm})$. Preoperative needle localizations were performed in 10 patients under computerized tomographic guidance. A conversion to open thoracotomy was needed in 4 patients, including 2 cases in which wedge resection was needed for a sufficient tumor margin $(>20 \mathrm{~mm})$. The histologic diagnoses of the resected specimens revealed 27 primary lung cancers (25 adenocarcinomas, 1 squamous cell carcinoma and 1 small cell carcinoma ), 3 atypical adenomatous hyperplasias, 2 hamartomas, 6 inflammatory lesions and 2 intrapulmonary lymphnodes. The mean tumor diameter of the 27 lung cancer lesions was $10.9 \mathrm{~mm}$ (ranged from 3 to $22 \mathrm{~mm}$ ), and 18 of the 27 cases were very small, $10 \mathrm{~mm}$ or less in diameter, lesions. After a definitive diagnosis of primary lung cancer was obtained, lobectomy and mediastinal dissections were performed in 18 patients, and segmentectomy and mediastinal dissection in 1 patient. In 8 patients, additional pulmonary resection was not performed. All 27 patients of primary lung cancer have survived without recurrence in the 18-month median follow-up period. Early detection by spiral computed tomography and thoracoscopic excisional biopsy (wedge resection) for diagnosis and treatment are thought to be useful to improve the prognosis of primary lung cancer.
\end{abstract}

